\title{
Co-creation in learning and teaching: the case for a whole-class approach in higher education
}

\author{
Catherine Bovill ${ }^{1}$ \\ Published online: 2 December 2019 \\ (C) The Author(s) 2019
}

\begin{abstract}
There is a wide range of activity in the higher education sector labelled 'students as partners' and 'co-creation in learning and teaching'. Several frameworks have been proposed to map and categorise existing partnership and co-creation roles, activities, research, and practice. In this paper, I synthesise some of these frameworks to illustrate how the predominant focus in the international literature has been on partnership projects that select small groups of often already super-engaged or privileged students to participate. In contrast, co-creation in learning and teaching, embedded within the curriculum and involving a whole class of students, has been largely overlooked. I explore the potential of co-creating learning and teaching with a whole class of students (including face-to-face, blended, and online settings, and including lectures, tutorials, laboratories, and other methods of teaching); in other words, it is co-creation integral to students' programmes and courses of study. I argue that whole-class approaches to co-creation may be inherently more inclusive of students than other approaches to co-creation and that this approach both relies upon, and contributes towards, building positive relationships between staff and students, and between students and students. I explore some of the challenges of whole-class co-creation in learning and teaching, and I also argue that the benefits suggest this is currently an underutilised and researched approach internationally.
\end{abstract}

Keywords Co-creation · Partnership · Whole class · Teaching approach · Staff-student relationships $\cdot$ Inclusion

\section{Introduction to co-creating learning and teaching}

In higher education, there has been rising interest in research and practice about 'students as partners' and co-created learning and teaching (Cook-Sather et al. 2014; Dunne 2016; Mercer-Mapstone et al. 2017). Although relatively widespread, this work has taken place

Catherine Bovill

catherine.bovill@ed.ac.uk

1 Institute for Academic Development, University of Edinburgh, 1 Morgan Lane, Edinburgh, Scotland EH8 8FP, UK 
predominantly in the USA, Canada, UK, Australia, and Scandinavia, and Dunne (2016) highlights that people are using many terms to describe this work. One commonly used term is student engagement, which refers to a very broad range of activities universities employ to motivate and interest students, as well as the time and effort students give to meaningful activities (Kuh 2009). Student engagement in the UK refers to both engagement in learning and teaching as well as engagement in student representation and governance systems. Student engagement also refers to low levels of engagement, such as a student turning up to class, as well as to high levels of engagement, such as a student going beyond course requirements. In contrast, partnership or 'students as partners' refers to a much deeper level of student involvement and agency. Cook-Sather et al. (2014: 6-7) define partnership in learning and teaching as 'a collaborative, reciprocal process through which all participants have the opportunity to contribute equally, although not necessarily in the same ways, to curricular or pedagogical conceptualization, decision making, implementation, investigation, or analysis'. A third term, co-creation, has been described by Ryan and Tilbury (2013) as a new pedagogical idea that emphasises learner empowerment. Bovill et al. (2016: 197) suggest that 'one way to conceptualise co-creation is occupying the space in between student engagement and partnership, to suggest a meaningful collaboration between students and staff, with students becoming more active participants in the learning process, constructing understanding and resources with academic staff.' Another related, but slightly broader term is participatory design. Participatory design refers to a collaboration of a group of stakeholders (often including external participants as well as teachers and students) in the design and development of initiatives, which can include the curriculum. All stakeholders' expertise is valued, but there is a strong focus on development of new technology and school-level design in much of the participatory design literature (DiSalvo et al. 2017) and students are often considered informants or testers rather than partners with high levels of agency (Martens et al. 2019).

The terms, students as partners, partnership, and co-creation of learning and teaching are often used interchangeably. I have chosen to use the term co-creation predominantly in this paper for a number of reasons: co-creation does not assume the level of equality sometimes implied by partnership, teaching staff are sometimes resistant to using the term partnership (my experience suggests some colleagues find the radical overtones of the term threatening and they disengage from conversations about partnership), and the term 'students as partners' has been critiqued for only naming one of the partners involved in the partnership (Cook-Sather 2018). Outside of an 'inner partnership circle' (made up of key authors of partnership articles and editors of partnership journals), I have found that many staff and students prefer to talk of striving for meaningful relationships, which may, due to the nature of higher education structures and assessment processes, fall short of what many consider to be true partnership. However, they are often keen to discuss students' active participation, learner empowerment, shared decision-making, student agency, and negotiation of learning and teaching under the umbrella of co-creation.

There is huge variation in the types of co-creation being enacted around the world, with work focusing on different activities, actors, and aims, for example, students co-researching university-wide projects and acting as change agents (Dunne and Zandstra 2011), students undertaking research and scholarship projects with staff (Werder and Otis 2010), student representatives collaborating with university staff on committees for quality assurance and enhancement purposes (Luescher-Mamashela 2013; Buckley 2014), students participating in course design review committees (Mihans et al. 2008; Rock et al. 2015), students as consultants providing feedback on teaching observations (Cook-Sather et al. 2014; Huxham et al. 
2017), students designing their own essay titles (Cook-Sather et al. 2014), students and teachers co-assessing work (Deeley 2014), students co-designing courses and curricula (Bovill 2014; Delpish et al. 2010), students co-evaluating courses (Bovill et al. 2010), students and staff writing collaboratively (Marquis et al. 2016), and students involved in teaching and designing academic development work (Kandiko Howson and Weller 2016). Cook-Sather et al. (2014: 209) have likened this to a 'partnership movement', but it is a movement embracing a diversity of focus, motivations, methods, values, and outcomes. One of the challenges raised by this rich diversity is ensuring clarity about the nature of work being described, researched, and discussed internationally. For researchers to build upon existing evidence, and to enable deeper discussions and understandings to develop within the field, this clarity is currently much needed.

In response, Bovill et al. (2016) outlined a typology of four roles that students adopt in cocreation work: representative, consultant, co-researcher, and pedagogical co-designer. There can often be overlap between the roles, but this model enables us to distinguish between the student representative role, which tends to be an elected role involving a small group of students representing a larger group of students; the consultant or intern role, which often involves students being selected by staff, and usually paid to collaborate on projects; and the co-research and pedagogical co-designer roles, where students may or may not be selected depending on if teachers choose to work with a small group or a whole class of students. In an alternative categorisation, Buckley (2014) has suggested that student engagement work (which encompasses much partnership and co-creation work) divides into two main areas of focus: the pedagogical and the political, with the former focused on learning and teaching and the latter focused on university governance. Finally, in a third typology, Bryson et al. (2015) propose that existing student partnership work can be categorised by the students who are involved in partnership. Model A partnership is work that involves only a small selection of students working with staff, and model B partnership is work involving all students within the curriculum. There are further related frameworks that I have not included here in order to avoid unnecessary complexity. Bovill and Woolmer (2018: 5) distinguish between co-creation of the curriculum (co-design of a programme or course, usually before the programme or course takes place) and co-creation in the curriculum (co-design of learning and teaching within a course or programme usually during the course or programme). In this paper, I focus specifically on whole-class co-creation in learning and teaching (co-creation taking place involving all students studying a course as the course unfolds). In the next section, I will explain this concept further and provide examples.

\section{Whole-class approaches to co-creation in learning and teaching}

Whole-class co-creation in learning and teaching involves inviting a whole group of students who are studying together in any teaching setting face-to-face or online, to actively collaborate and negotiate with the teacher and each other, elements of the learning process. This might include negotiation of the content or subject matter, the purpose of their work, the teaching approach, the many ways in which they can work and learn together, or their preferred approach to evaluation. When I refer to co-created learning and teaching, I include assessment. I could use the term co-created curriculum, but in this paper I purposely avoid the term curriculum to avoid further complexity due to the widespread lack of agreement over how higher education curriculum is defined and the resulting influence on what students are invited 
to co-create (Bovill and Woolmer 2018). Co-creation overlaps with the concept of active learning, which aims to move the student from adopting a passive role in learning to an active role involving interaction between teacher and students, and between students and students. Active learning practices and definitions vary, but it often involves students participating, interacting, or contributing, whether mentally or physically, in activities to gather information, to problem-solve, and to reflect upon knowledge. This often involves, for example, activities such as reading, writing, discussion, and small group work, as well as values and attitude exploration (Bonwell and Eison 1991; Freeman et al. 2014; Michael 2006). In co-creation, the purpose, approaches, and outcomes of learning and teaching are jointly negotiated and there is a shared responsibility for learning that implies a greater level of student agency and empowerment than in active learning. Co-creation involves developing deeper relationships between student and teacher, and between students and other students. Education is perceived as a shared endeavour where learning and teaching are done with students not to them (CookSather et al. 2014).

While there are many examples and significant discussion in the research literature of partnership and co-creation projects involving small numbers of students, there are relatively few examples in the international literature of whole-class co-creation in learning and teaching within higher education (Bryson et al. 2015; Mercer-Mapstone et al. 2017). This lack of attention to pedagogically embedded forms of co-creation between a teacher and a whole class of students is a distinct weakness in the current literature, which this paper aims to highlight. There are likely to be more instances of whole-class co-creation in practice that have not been captured in written accounts, but which teachers who have a disposition towards more democratic forms of teaching that encourage greater student agency, might describe as 'just the way I teach'. However, this highlights a key question about co-creation in learning and teaching, namely, how does it differ from good teaching? It is perfectly possible for a student to be engaged and to learn without co-creating learning and teaching. A teacher might use research evidence to support using interactive teaching approaches for the benefit of students (Freeman et al. 2014), but good teaching does not necessarily require a shift in the power relations between teacher and students that is required for co-creation. Care is also needed not to assume that good quality evidence-informed teaching involving active learning is common, despite growing evidence that we should 'question the continued use of traditional lecturing in everyday practice' (Freeman et al. 2014: 8413).

Another key consideration in discussing co-creation is to be careful about any claims made about the scale of co-creation. In a recent UK research study, Mercer-Mapstone and Bovill (2019) highlight that many institutional partnership schemes (the common terminology applied to university-level schemes funding collaborative projects) that might be considered large scale in fact reach less than 100 students per year because they involve multiple projects but each project only includes small numbers of students (with a couple of exceptions). The authors question whether some co-creation work that is considered small scale - such as whole-class cocreation led by individual, motivated members of staff - are in actual fact reaching larger numbers of students per year than many institutional schemes. Many 'large scale schemes' are being administered and funded at a macro-level but with predominant influence and impact at departmental level. In contrast, micro-level partnership activity within students' programmes of study is often considered small-scale and isolated despite involving potentially larger numbers of students. This is a key point I wish to emphasise because it has substantial implications for universities and departments wishing to increase co-creation activity. Several apparently isolated but motivated members of staff co-creating learning and teaching with their classes could involve 
a moderate number of students in co-creation (depending on the size of their classes) and thereby have significant impact on students. Motivating more members of staff to teach in ways that embed co-creation may be a powerful way of scaling up co-creation activity - a point that is somewhat overlooked within much of the partnership and co-creation literature.

Examples of whole-class co-creation include teachers who invite their student group to collaborate in decision-making throughout the course. Huxham et al. (2015) describe work with a whole class of ecology students at Edinburgh Napier University in Scotland. They refer to their work as 'a series of attempts to imagine the curriculum and our relationships in different ways' (p531) including moving some of the teaching outside the classroom into alternative spaces such as the local botanic gardens. They worked with 35 final year students to collaboratively decide the course direction. Using a metaphor from mountaineering, they referred to students as 'co-navigators' of the course (p531) and the course progressed by 'moving together' (p532). Fundamental to the approach taken was ' $\ldots$ the absence of a predetermined plan of action for every stage of the course' (p538). They argue that ' $\ldots$ the principles - of mutual respect, genuine sharing of control and rethinking the parameters of time and space to suit what is most appropriate for the type of knowledge students are engaging with - could apply in most disciplinary areas' (p540).

In another example outlined by Cook-Sather et al. (2014), Ignacio Canales taught an Entrepreneurship and Business Planning course at St Andrews University. Students were invited to design group projects to create a business idea. The whole class then collaborated to co-create the later part of the course by identifying key concepts and content needed in order to meet the requirements for students' proposed group projects. Students read key articles and resources and took turns to use engaging and entertaining approaches to introduce the important ideas from these readings to the rest of the class.

Bovill (2014) describes the work of Eurig Scandrett at Queen Margaret University, Edinburgh, who co-created an environmental justice programme with 16 students who were activists in their local community. The framework for each course was provided in the form of overarching themes/key areas of study such as understanding science, using the law and practical organisation. Students then co-created the content of the courses on the basis of the particular environmental injustices they wished to actively challenge, such as a toxic waste dump in a residential area.

Other examples of practice involve teachers working with a whole class of students to make decisions about selected elements of a course such as assessment. Deeley (2014) describes her work to introduce co-assessment in a Public Policy service learning course with eight, third and fourth year students at the University of Glasgow. 'Each student self-assessed her own oral presentation in addition to the teacher assessing each presentation. A provisional mark was awarded for the content and delivery of the presentation, and reflective comments were written by each student and the teacher. Subsequently, the teacher met individually with each student, to discuss the presentation using the written feedback comments as supportive evidence, and to agree a mark to co-assess presentations with students' (Deeley 2014: 43). Deeley and Bovill (2017) describe a range of initiatives where a whole class of students in a Public Policy course at the University of Glasgow were invited to co-create elements of assessment. The course involved 20 third and fourth year students, co-creating essay titles as well as the marking criteria for formative assessment and marking criteria for the summative examination. In each of these examples, it is important to note that these approaches to assessment might not be suitable for all programmes, such as final year courses with professional body accreditation, but they help to provide ideas of how co-creating assessment might be possible. 
Bovill et al. (2010) outline how a class of 20 postgraduate students co-created the evaluation for the educational research module they were studying. Students designed evaluation approaches to investigate elements of the course they were most interested in. They used a range of different evaluation methods that they considered suitable for eliciting information. Students and the teacher then collated and reflected on the evaluation outcomes as well as disseminating the findings within the programme teaching team.

Ayesha Delpish at Elon University in North Carolina worked with first year students studying a statistics course to create an 'open-ended, student-driven structure' to the course. From the first day of the course, she attempted to share power with students through using a series of real-world case studies which required students to work together in groups to solve. The cases provided the stimulus for students to create questions to solve the cases - the questions became the focus for the course and the basis of shared decision-making. 'For example, any question raised by a student during class went back to the entire group with a simple What do you think and why?' (Delpish et al. 2010: 108). She also invited students to be active participants in all the class learning activities.

Bergmark and Westman (2016) investigated the impact of co-creating the curriculum with two cohorts of 35 students on a school teacher education programme at Luleå University of Technology in Sweden. Teachers are normally '... required to present a study guide (a detailed plan of course activities) two weeks before class begins. However, in order to promote student engagement, there was no completed study guide before the course started. Instead, the lead instructor posted a tentative study guide and information about the first session and invited the students to plan the course together with the teacher. Then, based on the learning goals of the course, they created assignments related to the content of the course, including the literature' (Bergmark and Westman 2016: 32).

Students in these examples are much more responsible for what takes place in the learning environment. This does not imply the end of disciplinary knowledge, theoretical frameworks, or staff expertise (Breen and Littlejohn 2000), or that student views should be accepted uncritically. On the contrary, students and staff can critique knowledge together using shared expertise and perspectives. This co-creation approach recognises that knowledge is contingent and messy, and it accepts that students can play a role in knowledge co-creation. Students are making sense of what they are learning collaboratively with their teacher and peers.

\section{Outcomes and advantages of a whole-class approach to co-creation}

In much of the literature on partnership and co-creation, the evidenced outcomes are amalgamated across the wide range of different partnership and co-creation approaches adopted. These often involve outcomes for small numbers of students who experience an intense level of engagement through partnership or co-creation. To my knowledge, there has been no attempt to gather the outcomes from whole-class co-creation specifically. In Table 1, I present the outcomes specifically from whole-class co-creation in learning and teaching from the examples previously presented. This is not a comprehensive overview of all whole-class cocreation examples or outcomes, but helps to fill an existing gap in the partnership and cocreation literature.

In many of these studies, students and staff describe the importance of greater dialogue and of building relationships between students and staff and between students and students as an integral part of learning and teaching. Also highlighted is the changing nature of the power 
Table 1 Outcomes of whole-class approaches to co-creation

\begin{tabular}{|c|c|c|}
\hline Outcome & $\begin{array}{l}\text { Who experiences } \\
\text { outcome? }\end{array}$ & Source of evidence \\
\hline $\begin{array}{l}\text { Improved academic performance or higher } \\
\text { quality of work from students }\end{array}$ & Students & $\begin{array}{l}\text { Bovill (2014); } \\
\quad \text { Deeley and Bovill (2017) }\end{array}$ \\
\hline $\begin{array}{l}\text { Enhanced skills for future professional } \\
\text { development including teamwork, critical } \\
\text { reflection, and communication skills }\end{array}$ & Students & Deeley (2014) \\
\hline $\begin{array}{l}\text { Learning beyond the course and transferring } \\
\text { learning into new contexts/greater aca- } \\
\text { demic aspirations }\end{array}$ & Students & Bovill et al. (2010) \\
\hline $\begin{array}{l}\text { Opened up the learning process } \\
\text { to be more transparent }\end{array}$ & Students & Deeley (2014); Bovill et al. (2010) \\
\hline Process was fun & Students & Bovill et al. (2010) \\
\hline Shift from a focus on grades to learning & Students & Delpish et al. (2010) \\
\hline $\begin{array}{l}\text { Increased confidence, enthusiasm, } \\
\text { engagement, and motivation }\end{array}$ & Students & $\begin{array}{l}\text { Bergmark and Westman (2016); } \\
\text { Bovill (2014); Bovill et al. (2010); } \\
\text { Deeley (2014); } \\
\text { Deeley and Bovill (2017) }\end{array}$ \\
\hline $\begin{array}{l}\text { Increased autonomy, self-regulation, } \\
\text { and responsibility }\end{array}$ & Students & Deeley and Bovill (2017) \\
\hline Increased ownership & Students & $\begin{array}{l}\text { Bovill et al. (2010); Deeley (2014); } \\
\text { Deeley and Bovill (2017) }\end{array}$ \\
\hline $\begin{array}{l}\text { Appreciated learning by doing and learning } \\
\text { collaboratively with other students }\end{array}$ & Students & $\begin{array}{l}\text { Bergmark and Westman (2016); } \\
\text { Bovill et al. (2010) }\end{array}$ \\
\hline Practice at working democratically & Students & Bergmark and Westman (2016) \\
\hline Appreciated being asked to voice opinions & Students & $\begin{array}{l}\text { Bergmark and Westman (2016); } \\
\text { Deeley (2014); } \\
\text { Deeley and Bovill (2017) }\end{array}$ \\
\hline Felt valued & Students & Deeley and Bovill (2017) \\
\hline $\begin{array}{l}\text { Developed and experienced a more equal } \\
\text { relationship with the teacher }\end{array}$ & Students & Bovill et al. (2010) \\
\hline $\begin{array}{l}\text { Lack of familiarity, shock at being invited to } \\
\text { co-create course }\end{array}$ & Students & $\begin{array}{l}\text { Bergmark and Westman (2016); } \\
\text { Bovill (2014) }\end{array}$ \\
\hline $\begin{array}{l}\text { Enhanced identity, metacognitive awareness } \\
\text { of learning and teaching, inspired, and/or } \\
\text { transformed }\end{array}$ & Students and staff & $\begin{array}{l}\text { Bergmark and Westman (2016); } \\
\text { Bovill (2014); Huxham et al. (2015) }\end{array}$ \\
\hline Creation of a learning community & Students and staff & Deeley and Bovill (2017) \\
\hline Enhanced negotiation experience and skills & Students and staff & Bovill (2014); Deeley (2014) \\
\hline Curriculum becomes more (socially) relevant & Students and staff & Bovill (2014); Bovill et al. (2010) \\
\hline Student and teacher roles change & Students and staff & Bergmark and Westman (2016) \\
\hline Felt risky and unpredictable & Staff & $\begin{array}{l}\text { Bergmark and Westman (2016); } \\
\text { Bovill (2014); Delpish et al. (2010) }\end{array}$ \\
\hline $\begin{array}{l}\text { Challenge in getting the pace } \\
\text { of teaching right }\end{array}$ & Staff & Huxham et al. (2015) \\
\hline
\end{tabular}

dynamics and relationship between teacher and students: 'we were treated as equals from day one' (Bovill et al. 2010: 149). Two important potential benefits of whole-class co-creation in learning and teaching are worthy of further exploration. First, several authors have argued that whole-class co-creation is inherently more inclusive than co-creation approaches that involve selecting students to participate (Bovill et al. 2016; Bryson et al. 2015; Moore-Cherry et al. 2016). Second, I propose here that whole-class approaches require, but also enhance, positive relationships between the teacher and a whole group of students, and between the students in a 
class. I explore these two benefits further here, before discussing some of the challenges of whole-class co-creation in learning and teaching.

\section{Enhanced inclusion}

Bryson et al. (2015) argue that model A initiatives (involving selection of students) have some compelling benefits but that these are only available to a small number of students. The (s)election of students includes a tendency to involve students who are already engaged or advantaged in some way, potentially exacerbating existing inequalities and not tackling lower levels of student engagement. This runs the risk of creating a small 'elite' of super-engaged students and co-creation projects being perceived as only for privileged students (MercerMapstone and Bovill 2019; Cook-Sather 2018; Marquis et al. 2018). Even where partnership and co-creation schemes claim to be open to all, institutional and systemic forms of discrimination ensure that those students selected are likely to be already privileged in some way (Eddo-Lodge 2017; Mercer-Mapstone and Bovill 2019).

If the focus of co-creation is on students' learning, there is a strong ethical imperative that opportunities should be accessible to all students. Most institutions are too big to consider offering institutional partnership project opportunities for every student through partnership schemes. While these projects have been demonstrated to lead to a range of benefits, whole-class co-creation involving a teacher and a whole class of students offers a practical way to offer opportunities for co-creation to all students in a class. If there was an intentional effort by departments and institutions to support teachers to adopt teaching approaches that promote deep engagement through greater levels of student agency and shared decision-making, the benefits of co-creation could be experienced by larger numbers of students. This call for expansion of whole group co-creation requires a shift to the ways that people teach and learn, and has significant implications for the support offered to staff for teaching and learning enhancement.

Nevertheless, offering the opportunity to co-create learning with a whole class of students does not guarantee full participation and inclusion. As Cornwall argued 'the question of who participates - as well as who is excluded and who excludes themselves - is a crucial one' (Cornwall 2008: 275). Students may be invited to co-create learning and teaching, but they may not wish to. Cook-Sather et al. (2014) have argued that what is important is the equality of opportunity to participate, but also the opportunity not to participate - it is natural that students will participate in different ways. In order to be inclusive, teachers need to ensure that any opportunities to participate are genuinely open to all, and that the methods used to discuss and enact co-creation are clear, appeal to a diversity of students, offer different ways of being involved to suit different students' strengths, and are cognisant of students' different previous experiences, and socio-economic and cultural backgrounds. Specific strategies are needed to create a welcoming and reconceptualised learning environment that is genuinely open to allnot 'a few' or 'nearly all'-students.

All of this demands that teachers think carefully about different possible kinds of student involvement and ultimately a plan B (and C and often D) in case some students do not wish to participate. This is particularly important if a student does not want to be involved in cocreating assessment. Staff need to ensure there are well-considered plans in place that do not detrimentally impact on students' grades, and this needs to be weighed against the evidence of enhanced performance from students involved in co-creation. If someone strongly resists participating in an activity, usually, teachers would use forms of negotiation to try to explain 
the benefits of what they are proposing or would offer equally valuable alternatives. It is easier to appeal to encourage all students to participate in some way where there is an expectation that the whole class is working together towards a shared purpose that has been negotiated. And yet, we need to overcome the idea that within any class, students must participate at the same level and in the same way and at the same time (Bovill 2017); this is simply unrealistic and does not take into account the variations of motivation and engagement in class or online at any one time.

\section{Building positive relationships}

There is robust evidence to show that positive student-teacher relationships in higher education lead to a host of benefits. Greater student-teacher interaction inside and outside formal classes can lead to students' academic success, good academic performance, higher educational aspirations, personal and intellectual development, student satisfaction, and enhanced motivation (see, for example, Chickering and Gamson 1987; Cuseo 2007; Komarraju et al. 2010; Kuh and Hu 2001; Lamport 1993; Lundberg and Schreiner 2004; Pascarella and Terenzini 1978, 2005). Academic staff characteristics and attitudes are also considered a key influence on any teaching environment and on establishing positive relationships with students, which in turn are key predictors of positive student engagement and achievement outcomes (Powell 1976; Scheck and Bizio 1977; Theophilides and Terenzini 1981). Staff perceived as being warm and informal, friendly, genuine, respectful, and understanding, support the development of positive teacher-student relationships (Theophilides and Terenzini 1981). McDowell and Westman (2005) noted that staff who encourage students to call them by their first names are perceived as warmer, more approachable, and more respectful than staff who are addressed by formal titles.

Early teacher-student and student-student encounters are crucial in relationship building. Gozemba (2002: 132) reports a student saying to her, 'When you come to class on the first day and the teacher says 'We notice your attitude,' they forget that we notice their attitude too. Students do the same thing'. Time is needed to build trust and respect, and the teacher needs to demonstrate that they value contributions from all students in the group. Whole-class cocreation also relies on teachers being prepared to relinquish some of their power and on their valuing students' contributions. As De Los Reyes (2002: 49-50) argues, it is important for teachers to take the first steps in creating a trusting relationship: '...the teacher needs to make it clear that he or she is interested in sharing power by giving students room to participate'. Breen and Littlejohn (2000: 277) highlight '...teachers may need to come to see their own plans for classroom work as simply proposals... which learners have the right to reformulate, elaborate upon or even reject.' Respect, responsibility, and reciprocity are considered underpinning principles for working in partnership (Cook-Sather et al. 2014), and it could be argued also for co-creating learning and teaching with students. These values align well with many of the factors that have been demonstrated to build positive relationships between teachers and students in co-created learning and teaching.

Positive student-teacher relationships are at the heart of co-created learning and teaching. Co-creation relies on students and teachers trusting and respecting one another, and recognising that responsibility for learning is shared, in the case of whole-class cocreation, by the entire group. If we look at the evidence in Table 1, it appears that positive relationships are not just a key element needed for co-creation but they are also an outcome of co-creation. 


\section{Challenges of a whole-class approach to co-creation}

Co-creating learning and teaching with an entire class is not without challenges (Bovill et al. 2016), including, but not limited to, time constraints, large classes, 'sticky' classes, gaps between espoused and actual practice, and sustaining co-creation.

\section{Time constraints}

Most academic staff and students experience time pressure, which can be a challenge to co-created learning and teaching where additional planning may be required to adapt previous ways of working and time is also needed to build trust. From talking to practitioners who are co-creating learning and teaching, I get the sense that they are not people with excessive time on their hands, but rather they are re-prioritising their time, either in response to the evidence of positive outcomes from co-created learning and teaching or because they are seeking more engaging or democratic kinds of teaching in which students have more agency. Whole-class co-creation is perhaps less about requiring extra time and more about different ways of relating to one another, which involve negotiation and shared decision-making within existing class time.

\section{Large classes}

The market context within which many universities operate leads to increasing pressure for many institutions to expand class sizes. Yet, the adverse effects of large class sizes are well evidenced (Cuseo 2007) and include the following: causing staff to rely on lectures as the primary teaching approach, reducing the level of active involvement of students, reducing the frequency and quality of teacher-student interaction, reducing students' depth of thinking in class, increasing the use of assessments that take less time to grade, reduction in students' learning and their grade performance, and reports of lower student satisfaction (Cuseo 2007). Gibbs (2010) also notes teacher-student interaction in large classes tends to focus on fact clarification, in contrast to smaller classes where students and staff engage in more dialogue and thought exploration. Therefore, smaller classes may be more conducive to enacting deeper forms of interaction, negotiation, and power sharing that are necessary for co-creation. This implies whole-class co-creation in learning and teaching may be possible but challenging in large classes.

\section{'Sticky' classes}

Academic staff from different disciplines, including those who engage in co-creation, often report experiencing a particularly problematic class, where they use a range of similar teaching approaches or invitations to students to participate, to those they have used in previous years, but whatever they do, this particular group is resistant. They talk of becoming frustrated when they seem to make little progress with these 'sticky' classes. Even the greatest supporters of radical pedagogical approaches sometimes have a sticky class: '...I had this class that I just hated. I hated it so bad I didn't want to get up in the morning and go to it...One of the things that fascinated me about that experience is that we failed to create a learning community in the classroom. That did not mean that individual students didn't learn a great deal, but in terms of creating a communal context for learning, it was a failure. That failure was heartbreaking for 
me. It was hard to accept that I was not able to control the direction our classroom was moving in. I would think, 'What can I do? And what could I have done?' And I kept reminding myself that I couldn't do it alone, that forty other people were also in there' (hooks 1994: 158-159). This is a powerful reminder that a teacher is not in sole control of what happens in any class. We need to develop a wide range of strategies if we wish to communicate our intentions to share power with students. We also need to remember that many students have become used to the passive role through the widespread use of 'traditional lecturing' and unidirectional approaches to teaching (Freeman et al. 2014).

\section{Gaps between espoused and actual practice}

There are some staff who claim to be co-creating learning and teaching, but the ways they talk about and behave towards students reveal a disconnect between espoused values and practice (Bovill 2015). Indeed, some staff may struggle to relinquish power-they prefer to remain in control of teaching rather than face the risk of uncertainty in opening teaching to be a co-created endeavour. What if students prioritise different things from the teacher or feel they do not have legitimate contributions to make? What if the teacher invites students to participate but does not value student contributions? hooks (1994: 8) argued that 'to begin, the professor must genuinely value everyone's presence. There must be an ongoing recognition that everyone influences the classroom dynamic, that everyone contributes'. This is a vision of an inclusive classroom where everyone has opportunities but also responsibilities. hooks continued by suggesting that 'all too often we have been trained as professors to assume students are not capable of acting responsibly, that if we don't exert control over them, then there's just going to be mayhem' (hooks 1994: 152). The strong relationships, trust, and shared decision-making at the heart of co-creating learning and teaching require a focus on teacher and student attitudes, language, and behaviour towards one another.

\section{Sustaining co-creation}

Moore (2004) talks of the effort that it takes to maintain a more participatory approach to work over several years, and in Table 1, several studies highlight the sense of risk experienced by some staff. In contrast, other staff have described whole-class co-creation in learning and teaching as transformatory and invigorating: 'It was liberating ... we moved from teaching ... that just didn't work to ... [teaching]... that ... was put together in ways that I never even imagined were possible ... so... it's really transformed how I think about teaching and how I teach' (Bovill 2014: 18). However, we need to consider what we mean by sustainability. There is a substantial difference between (1) a co-creation project where a small group of selected students redesign a course they previously studied, and which may then not be substantially updated for a number of years, and (2) a whole class co-creation approach where a teacher opens up the learning and teaching experience for negotiation, and redesign of the course each time she meets a new class of students. Whole-class co-creation in learning and teaching requires the teacher to be responsive to the needs of each new group of students. Whole-class co-creation also requires a teacher to adopt a potentially career-long commitment to engage deeply with each new group of students encountered and to mutually negotiate each new learning encounter. This is a seismic change to the way that much learning and teaching is conducted within universities. 


\section{Conclusions}

The growth of interest and activity related to co-creation and partnership over the last 5 to 10 years is encouraging, but has focused predominantly on project-based initiatives involving small groups of students (Mercer-Mapstone et al. 2017). In contrast, wholeclass co-creation in learning and teaching has received relatively little attention in the literature. Increasing whole-class co-creation has the potential to transform teaching and learning practices and to reach greater numbers of students with more democratic forms of education. I would argue we need both approaches to partnership and co-creation to maximise the benefits that are increasingly being evidenced from these collaborative endeavours. If we draw on Freeman et al.'s (2014) argument, based on evidence of interactive learning, the growing evidence for the benefits of whole-class co-creation in learning and teaching suggests we could be held negligent for not ensuring all students have the opportunity to benefit. Indeed, Kuh (2009: 31) argues that in higher education, 'most institutions can increase student engagement and success by more consistently using what the research shows are promising policies and effective educational activities and practices...but at too many institutions, only small numbers of students are involved'.

We could also learn from related work that takes place in schools. Due to the class sizes in primary and high school, some authors draw attention to the potential of co-creation and negotiated curriculum with whole classes of students (see, for example, Bron et al. 2018). What differs in higher education is that class sizes are often substantially larger, and this poses a very real challenge to whole-class co-creation. Further exploration of school-based cocreation research and expertise would be of benefit to the higher education sector. Further research would also be beneficial that focuses on gathering more examples and outcomes from whole-class co-creation, particularly in larger classes.

Whole-class co-creation has the potential to be a more inclusive approach to co-creation and to support the building of positive relationships, which in turn are likely to contribute to wider departmental and institutional priorities of building more effective learning environments, a stronger sense of community and belonging. However, this may require academic staff in most cases to adapt their current teaching practice, and learn to adopt more relational approaches to teaching that are open, collaborative, dialogic, and democratic. They may need to learn how to facilitate collaborative decision-making with a whole class to ensure inclusion is maximised. This is likely to require many teachers to learn more about the benefits of wholeclass co-creation and about different ways to facilitate and evaluate whole-class co-creation. This has significant implications for departments and universities in terms of the academic development support offered to teaching staff.

Writing over 20 years ago, bell hooks argued that 'the classroom remains the most radical space of possibility in the academy' (hooks 1994: 12), but I would suggest we are not maximising this possibility. Also over 20 years ago, Lamport (1993: 980) argued that 'educational institutions need humanizing to regain the personal element. Sweeping changes are needed in attitudes toward teaching, learning and relations among faculty, students and administrators.' Our challenge inside and outside the curriculum is to ensure we speak and behave in ways that communicate our shared respect and care for one another. What students want ' $\ldots$ is teachers who care deeply about them, have enormously high standards, and believe in the potential of every student' (De Los Reyes and Gozemba 2002: 21), and this, in my view, is the key to enhancing much of what we do in universities. 
Acknowledgements Many thanks to Dr. Rayya Ghul, Dr. Daphne Loads, and Dr. Lucy Mercer-Mapstone for constructively critical comments on an earlier version of this paper.

Open Access This article is distributed under the terms of the Creative Commons Attribution 4.0 International License (http://creativecommons.org/licenses/by/4.0/), which permits unrestricted use, distribution, and reproduction in any medium, provided you give appropriate credit to the original author(s) and the source, provide a link to the Creative Commons license, and indicate if changes were made.

\section{References}

Bergmark, U., \& Westman, S. (2016). Co-creating curriculum in higher education: promoting democratic values and a multidimensional view on learning. International Journal for Academic Development, 21(1), 28-40.

Bonwell, C. C., \& Eison, J. A. (1991). Active learning: creating excitement in the classroom. Washington D.C.: George Washington University.

Bovill, C. (2014). An investigation of co-created curricula within higher education in the UK, Ireland and the USA. Innovations in Education and Teaching International, 51(1), 15-25.

Bovill, C. (2015). Identifying your underlying assumptions in co-creating learning and teaching: the importance of language and behaviour. Paper presentation, student voice conference, 22-24 June, University of Cambridge.

Bovill, C. (2017). A framework to explore roles within student-staff partnerships in higher education: which students are partners, when and in what ways? International Journal for Students as Partners, 1(1), 1-5.

Bovill, C., \& Woolmer, C. (2018). How conceptualisations of curriculum in higher education influence studentstaff co-creation in and of the curriculum. Higher Education https://ink.springer.com/article/10.1007 $\% 2$ Fs10734-018-0349-8.

Bovill, C., Aitken, G., Hutchison, J., Morrison, F., Roseweir, K., Scott, A., \& Sotannde, S. (2010). Experiences of learning through collaborative evaluation from a postgraduate certificate in professional education. International Journal for Academic Development, 15(2), 143-154.

Bovill, C., Cook-Sather, A., Felten, P., Millard, L., \& Moore-Cherry, N. (2016). Addressing potential challenges in co-creating learning and teaching: overcoming resistance, navigating institutional norms and ensuring inclusivity in student-staff partnerships. Higher Education, 71(2), 195-208.

Breen, M. P., \& Littlejohn, A. (2000). The practicalities of negotiation. In M. P. Breen \& A. Littlejohn (Eds.), Classroom decision-making: negotiation and process syllabuses in practice (pp. 272-295). Cambridge: Cambridge University Press.

Bron, J., Bovill, C., \& Veugelers, W. (2018). Distributed curriculum leadership: how negotiation between student and teacher improves the curriculum. Journal of Ethical Educational Leadership, Special Issue 1 March, 74-95.

Bryson, C., Furlonger, R., \& Rinaldo-Langridge, F. (2015). A critical consideration of, and research agenda for, the approach of 'students as partners'. Paper presentation, International Conference on Improving University Teaching, Ljubljana, Slovenia, 15-17 July.

Buckley, A. (2014). How radical is student engagement? (And what is it for?). Student Engagement and Experience Journal, 3(2). https://doi.org/10.7190/seej.v3i2.95.

Chickering, A. W. \& Gamson, Z. F. (1987). Seven principles for good practice in undergraduate education. AAHE Bulletin, March, 3-7, http://eric.ed.gov/?id=ED282491.

Cook-Sather, A. (2018). Listening to equity-seeking perspectives: how students' experiences of pedagogical partnership can inform wider discussions of student success. Higher Education Research and Development, 37(5), 923-936.

Cook-Sather, A., Bovill, C., \& Felten, P. (2014). Engaging students as partners in learning and teaching: a guide for faculty. San Francisco: Jossey Bass.

Cornwall, A. (2008). Unpacking participation: Models, meanings and practices. Community Development Journal, 43(3), 269-283.

Cuseo, J. (2007). The empirical case against large class size: adverse effects on the teaching, learning and retention of first-year students. The Journal of Faculty Development, 21(1), 5-21.

De Los Reyes, E. (2002). Breaking the cycle rising to question: the language intensive interdisciplinary program. In E. De Los Reyes \& P. A. Gozemba (Eds.), Pockets of hope: how students and teachers change the world (pp. 31-60). London: Bergin and Garvey.

De Los Reyes, E., \& Gozemba, P. A. (2002). Introduction: education as the practice of freedom. In E. De Los Reyes \& P. A. Gozemba (Eds.), Pockets of hope: how students and teachers change the world (pp. 1-30). London: Bergin and Garvey. 
Deeley, S. J. (2014). Summative co-assessment: a deep learning approach to enhancing employability skills and attributes. Active Learning in Higher Education, 15(1), 39-51.

Deeley, S. J., \& Bovill, C. (2017). Staff-student partnership in assessment: enhancing assessment literacy through democratic practices. Assessment and Evaluation in Higher Education, 42(3), 463-477.

Delpish, A., Holmes, A., Knight-McKenna, M., Mihans, R., Darby, A., King, K., \& Felten, P. (2010). Equalizing voices: student-faculty partnership in course design. In C. Werder \& M. Otis (Eds.), Engaging student voices in the study of teaching and learning (pp. 96-114). Sterling: Stylus.

DiSalvo, B., Yip, J., Bonsignore, E., \& DiSalvo, C. (Eds.). (2017). Participatory design for learning: perspectives from practice and research. Abingdon: Routledge.

Dunne, E. (2016). Design thinking: a framework for student engagement? A personal view. Journal of Educational Innovation, Partnership and Change, 2(1). https://doi.org/10.21100/jeipc.v2i1.317.

Dunne, E., \& Zandstra, R. (2011). Students as change agents. New ways of engaging with learning and teaching in higher education. Bristol: ESCalate, Higher Education Academy/University of Exeter.

Eddo-Lodge, R. (2017). Why I'm no longer talking to white people about race. London: Bloomsbury.

Freeman, S., Eddy, S., McDonough, M., Smith, M. K., Okoroafor, N., Jordt, H., \& Wenderoth, M. P. (2014). Active learning increases student performance in science, engineering and mathematics. Proceedings of the National Academy of Sciences of the USA, 111(23), 8410-8415.

Gibbs, G. (2010). Dimensions of quality. York: Higher Education Academy.

Gozemba, P. A. (2002). Aloha 'Aina. In E. D. L. Reyes \& P. A. Gozemba (Eds.), Pockets of hope: how students and teachers change the world (pp. 121-148). London: Bergin and Garvey.

hooks, b. (1994). Teaching to transgress: education as the practice of freedom. London: Routledge.

Huxham, M., Hunter, M., McIntyre, A., Shilland, R., \& McArthur, J. (2015). Student and teacher co-navigation of a course: following the natural lines of academic enquiry. Teaching in Higher Education, 20(5), 530-541.

Huxham, M., Scoles, J., Green, U., Purves, S., Welsh, Z., \& Gray, A. (2017). 'Observation has set in': comparing students and peers as reviewers of teaching. Assessment \& Evaluation in Higher Education, 42(6), 887-899.

Kandiko Howson, C., \& Weller, S. (2016). Defining pedagogic expertise: students and new lecturers as codevelopers in learning and teaching. Teaching \& Learning Inquiry, 4(2). https://doi.org/10.20343 /teachlearninqu.4.2.6.

Komarraju, M., Musulkin, S., \& Bhattacharya, G. (2010). Role of student-faculty interactions in developing college students' academic self-concept, motivation, and achievement. Journal of College Student Development, 51(3), 332-342.

Kuh, G. D. (2009). High impact activities: what they are, why they work, who benefits. In C. Rust (Ed.), Improving student learning through the curriculum (pp. 20-39). Oxford: Oxford Centre for Staff and Learning Development, Oxford Brookes University.

Kuh, G. D., \& Hu, S. (2001). The effects of student-faculty interaction in the 1990s. The Review of Higher Education, 24(3), 309-332.

Lamport, M. A. (1993). Student-faculty interaction and the effect on college student outcomes. Adolescence, 28(112), 971-990.

Luescher-Mamashela, T. M. (2013). Student representation in university decision making: good reasons, a new lens? Studies in Higher Education, 38(10), 1442-1456.

Lundberg, C. A., \& Schreiner, L. A. (2004). Quality and frequency of faculty-student interaction as predictors of learning: an analysis by student race/ethnicity. Journal of College Student Development, 45(5), 549-565.

Marquis, E., Healey, M., \& Vine, M. (2016). Fostering collaborative teaching and learning scholarship through an international writing group initiative. Higher Education Research \& Development, 35(3), 531-544.

Marquis, E., Jayaratnam, A., Mishra, A., \& Rybkina, K. (2018). "I feel like some students are better connected": students' perspectives on applying for extracurricular partnership opportunities. International Journal for Students as Partners, 2(1), 64-81. https://doi.org/10.15173/ijsap.v2i1.3300.

Martens, S. E., Meeuwissen, S. N. E., Dolmans, H. J. M., Bovill, C. \& Könings, K. D. (2019). Student participation in the design of learning and teaching: disentangling the terminology and approaches. Medical Teacher Short Communication, https://www.tandfonline.com/doi/full/10.1080/0142159 X.2019.1615610.

McDowell, J. E., \& Westman, A. S. (2005). Exploring the use of first name to address faculty members in graduate programs. College Student Journal, 39(2), 352-256.

Mercer-Mapstone, L., \& Bovill, C. (2019). Equity and diversity in institutional approaches to student- staff partnership schemes in higher education. Studies in Higher Education https://www.tandfonline. com/doi/abs/10.1080/03075079.2019.1620721. Accessed 13 July 2019.

Mercer-Mapstone, L., Dvorakova, S. L., Matthews, K. E., Abbot, S., Cheng, B., Felten, P., Knorr, C., Marquis, E., Shammas, R., \& Swaim, K. (2017). A systematic literature review of students as partners in higher education. International Journal for Students as Partners, 1(1), 1-23 https://www.researchgate. 
net/publication/316764140_A_Systematic_Literature_Review_of_Students_as_Partners_in_Higher_ Education. Accessed 13 July 2019.

Michael, J. (2006). Where's the evidence that active learning works? Advances in Physiology Education, 30(4), 159-167.

Mihans, I. I., Richard, J., Long, D. T., \& Felten, P. (2008). Power and expertise: student-faculty collaboration in course design and the scholarship of teaching and learning. International Journal for the Scholarship of Teaching and Learning, 2(2), 16.

Moore, J. (2004). Living in the basement of the ivory tower: a graduate student's perspective of participatory action research within academic institutions. Educational Action Research, 12(1), 145-162.

Moore-Cherry, N., Healey, R., Nicholson, D. T., \& Andrews, W. (2016). Inclusive partnership: enhancing student engagement in geography. Journal of Geography in Higher Education, 40(1), 84-103.

Pascarella, E., \& Terenzini, P. C. (1978). Student faculty informal relationships and freshman year educational outcomes. Journal of Educational Research, 71(4), 183-189.

Pascarella, E., \& Terenzini, P. (2005). How college affects students vol 2: a third decade of research. San Francisco: Jossey Bass.

Powell, J. P. (1976). Informal staff student contact at the University of NSW. In TERC research and development paper 42. Kensington: New South Wales University.

Rock, R., Foster, E., \& Lamb, S. (2015). Putting students at the heart of the curriculum change process. York: Higher Education Academy.

Ryan, A., \& Tilbury, D. (2013). Flexible pedagogies: new pedagogical ideas. York: Higher Education Academy. Scheck, D. C., \& Bizio, S. (1977). Students' perceptions of the ideal professor. College Student Journal, 11(4), 335-342.

Theophilides, C., \& Terenzini, P. C. (1981). The relation between non classroom contact with faculty and students' perceptions of instructional quality. Research in Higher Education, 15(3), 255-269.

Werder, C., \& Otis, M. (2010). Not the conclusion. Moving from engaging to sustaining student voices. In C. Werder \& M. Otis (Eds.), Engaging student voices in the study of teaching and learning (pp. 185-194). Sterling: Stylus.

Publisher's note Springer Nature remains neutral with regard to jurisdictional claims in published maps and institutional affiliations. 